\title{
KINETICS AND MECHANISM OF THE OXIDATION OF ORANGE II BY PERIODATE ION IN AQUEOUS ACID
}

\author{
${ }^{1}$ Myek, B., ${ }^{2}$ Idris, S. O., ${ }^{3}$ Onu, A. D. and ${ }^{4}$ Yakubu, M. K. \\ ${ }^{1}$ Department of Chemistry, Kaduna State University, Nigeria \\ ${ }^{2}$ Department of Chemistry, Ahmadu Bello University, Zaria, Nigeria \\ ${ }^{3}$ Department of Chemistry, Federal College of Education, Zaria, Nigeria \\ ${ }^{4}$ Department of Polymer and Textile Engineering, Ahmadu Bello University, Zaria, Nigeria \\ Corresponding Author's Email Address: bako.myek@kasu.edu.ng Phone: +2348095079101
}

(Received: June 6, 2020; Accepted: January 3, 2021 )

\section{ABSTRACT}

\begin{abstract}
The kinetics of the oxidation of orange $\mathrm{II}(\mathrm{OR})$ by periodate ion in acidic solution has been studied spectrophotometrically at various conditions viz- wavelength, $\lambda$ of $484 \mathrm{~nm}$, temperature, $\mathrm{T}$ of $23 \pm 1^{\circ} \mathrm{C}$, in the acid range $(2.0-10.0) \times 10^{-2} \mathrm{~mol} \mathrm{dm}^{-3}$ and ionic strength of $2.0-8.0 \mathrm{C}^{2} \mathrm{~mol} \mathrm{dm}{ }^{-3}(\mathrm{NaCl})$. The aim of this research was to carry out kinetic study and propose mechanisms of the redox reactions of orange II with periodate ion in acidic solution. The reaction shows a first order dependence on [oxidant] and [reductant]. The rate of the reaction increases with increase in $\left[\mathrm{H}^{+}\right]$. Plot of $\mathrm{k}_{1}$ versus $\log \left[\mathrm{H}^{+}\right]$gave a slope of one, showing that the reaction is first order with respect to hydrogen ion concentration. The Plot of $\mathrm{k}_{2}$ versus $\left[\mathrm{H}^{+}\right]$was linear with a positive intercept $\left(\mathrm{R}^{2}=0.89\right)$. The acid dependence of this nature shows that there is a rapid pre-equilibrium between the protonated and non-protonated forms in which both the protonated and unprotonated forms are reactive. The stoichiometry of the reaction is 1:1 $\left(\mathrm{OR}: \mathrm{IO}_{4}\right)$. Added cations decrease the rate of the reaction. The results of spectroscopic investigation indicated that no intermediate complex is probably formed in the course of this reaction. The reaction is probably operative through the outersphere mechanism
\end{abstract}

Key words: Kinetics, Periodate, Stoichiometry, Orange II

\section{INTRODUCTION}

Interest in periodate as an oxidant in electron transfer reactions has received much attention (Onuet al., 2009). It has been found that periodate readily oxidises both labile complexes and inert complexes, possessing at least one bridging ligand. Onuet al (2009) studied the kinetics of the reduction of tetraoxoiodate(VII) by $\mathrm{n}-(2-$ hydroxylethyl)ethylenediametriacetatocobalt(II) ion in aqueous perchloric acid. The stoichiometry of 2:1 was obtained and the reaction is first order with respect to both the oxidant and the reductant concentration and second orders overall. The importance of periodate in redox reaction prompted the choice of this oxidant for this research.

The azo dye (orange II) plays an important role in industries like textile, leather, plastics, paper and cosmetics among others. Azo dyes are characterized by the presence of one or more azo group $(-\mathrm{N}=\mathrm{N}-)$ in association with two or more aromatic or heterocyclic system (Olayinkaetal., 2013; Zainab et al., 2013; Gapalaet al., 2011).This dye is formed by coupling an aromatic diazonium ion with an activated aromatic substrate. Aromatic diazonium ions are electrophilic reagents that can attack aromatic rings and replace the hydrogens at activated positions in the ring(David, 2008).Comparative study on the decolorization of OR by zero-valence tin in citric and hydrochloric acid has been reported(Shizuo and Makoto, 2012). It was found that zero-valence tin reductively degraded a persistent azo dye, or to produce colourless aromatic amines. Degradation of Orange II dye has been studied mostly through a photocatalytic method. In spite of the oxidation of orange II in acidic medium, its redox reaction with periodate ion has not been reported. The aim of this research was to carry out kinetic study and propose mechanisms of the redox reactions of orange II with periodate ion in acidic solution.

\section{MATERIALS AND METHODS}

The chemicals used were of analytical grade and were used without further purification. Standard solution of OR was prepared by dissolving accurate weight of orange II dye in a known volume of distilled water. Sodium nitrite solution was prepared by dissolving known quantities in 
distilled water. All other reagents used were of analytical grade.

The stoichiometry of the reaction was determined spectrophotometrically using the mole ratio method by keeping the concentration of the dye constant at $5 \times 10^{-5} \mathrm{~mol} \mathrm{dm}^{-3}, \mathrm{H}^{+}=5.0 \times 10^{-2} \mathrm{~mol}$ $\mathrm{dm}^{-3}, \mathrm{I}=0.5 \mathrm{~mol} \mathrm{dm}{ }^{-3}, \lambda_{\max }=484 \mathrm{~nm}, \mathrm{~T}=23 \pm$ $1^{\circ} \mathrm{C}$. The stoichiometry was determined from the plot of absorbance versus [reductant]/ [oxidant] after the reaction had gone to completion by the observation of a steady zero absorbance value over a period of two days.

A UV-Vis spectrophotometer 6405 was used to follow the decrease in absorbance of the dye at $484 \mathrm{~nm}$. The kinetic runs were conducted under pseudo - first order conditions with $\left[\mathrm{IO}_{4}\right]$ in excess over OR. Temperature, ionic strength and hydrogen ion concentration were maintained constant. The pseudo-first order plots of $\log \left(A_{t}-\right.$ $A \infty$ ) versus time, were made (where $A_{t}$ and $A \infty$ are the absorbance at time $t$ and at the end of the reaction respectively). From the slope of the plots, the pseudo-first order rate constant $\left(k_{1}\right)$ was determined (Mohammed et al., 2008).

The effect of hydrogen ion concentration on the rate of reaction was investigated by varying $\left[\mathrm{H}^{+}\right]$in the range $(2.0-10.0) \times 10^{-2} \mathrm{~mol} \mathrm{dm}^{-3}$, while $\mathrm{OR}^{-}$and $\mathrm{IO}_{4}^{-}$were kept constant at $\mathrm{T}=23 \pm 1^{\circ} \mathrm{C}$ and $\mathrm{I}=$ $\left.0.5 \mathrm{~mol} \mathrm{dm} \mathrm{m}^{-3} \mathrm{NaCl}\right)$ respectively. The effect of ionic strength on the rate of the reaction was carried out in the range $2.0-7.0 \mathrm{~mol} \mathrm{dm}{ }^{-3}(\mathrm{NaCl})$ while the concentration of $\left[\mathrm{H}^{+}\right]$and $\left[\mathrm{IO}_{4}\right]$ were kept constant at $\mathrm{T}=23 \pm 1^{\circ} \mathrm{C}$.

The effect of added cations and anions were investigated by keeping the concentration of other reactants constant while varying the ions concentrations as follows: $[\mathrm{X}]=\left(1.0 \times 10^{-3}-100 \times\right.$ $\left.10^{-3}\right) \mathrm{mol} \mathrm{dm}^{-3}$, where $\mathrm{X}=\left(\mathrm{CH}_{3} \mathrm{COO}^{-}\right.$and $\left.\mathrm{SO}_{4}{ }^{2}\right)$ and $\left[\mathrm{X}^{+}\right]=\left(10.0 \times 10^{-3}-150 \times 10^{-3}\right) \mathrm{mol} \mathrm{dm}^{-3}$, were $\mathrm{X}=\left(\mathrm{Ca}^{2+}\right.$ and $\left.\mathrm{Mg}^{2+}\right)$

\section{RESULTS AND DISCUSSION}

The stoichiometric study showed that one mole of orange I I ( 4 - [ ( 2 - hydroge n- 1 naphthalenyl)azo]benzenesulfonic acid) was oxidized by one mole of $\mathrm{IO}_{4}^{-}$. The overall stoichiometry equation is represented in equation (1). A stoichiometry of 2:1 has been reported for the reduction of $\mathrm{IO}_{4}$ by indigo carmine (Edokpayi et al., 2010) and naphthol green B (Myek et al., 2013) in aqueous acid medium.

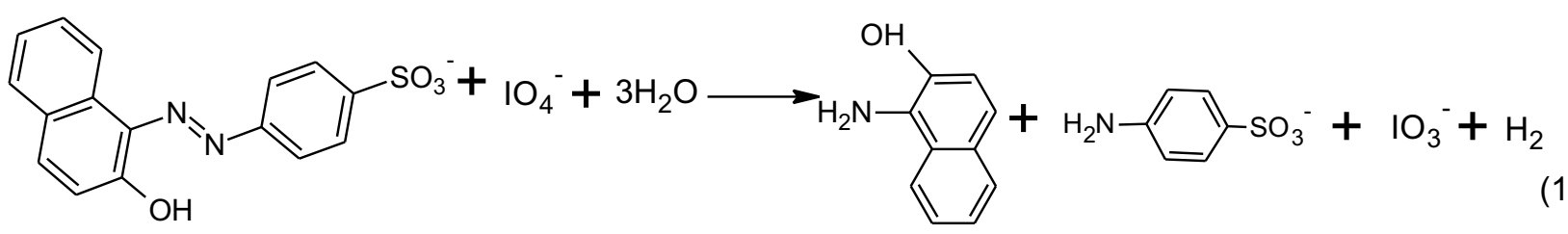

$\mathrm{Io}_{3}$ was confirmed as the inorganic product of this reaction (Svehla and Sivasankar's, 2012). This is in accordance with the findings of Onu et al (2009); that $\mathrm{IO}_{4}^{-}$is known to be reduced to $\mathrm{IO}_{3}{ }^{-}$in most of its reactions. This is illustrated in equation (2).

$\mathrm{IO}_{3}^{-}+5 \mathrm{I}^{-}+6 \mathrm{H}^{+} \longrightarrow 3 \mathrm{I}_{2}+3 \mathrm{H}_{2} \mathrm{O}$

Kinetic studies of the reaction of orange II and $\mathrm{IO}_{4}^{-}$showed that the reaction is first order in [OR] and $\left[\mathrm{IO}_{4}\right]$. Similar order was reported for the oxidation of hexacyanoferrate(III) by $\mathrm{IO}_{4}^{-}$(Idris et al., 2015), oxidation of ternary orotatochromium(III) complexes bearing oxalate or malonate co-ligands by periodate ion (Ismail et al., 2014), hexacyanoferrate(II) by periodate ion in highly alkaline aqueous medium (Naiket al., 2008), oxidation of L-Ascorbic acid by periodate ion in acidic medium (Babatunde and Nwakama, 2013) and oxidation of Methyldopa by Periodate ion (Kaushik etal., 2014).

The rate of this reaction is illustrated in equation 3

$-\mathrm{d}\left[\mathrm{OR}^{-}\right] / \mathrm{dt}=\left(\mathrm{a}+\mathrm{b}\left[\mathrm{H}^{+}\right]\right)\left[\mathrm{OR}^{-}\right]\left[\mathrm{IO}_{4}{ }^{-}\right]$ 
The rate of the reaction increases with increase in $\left[\mathrm{H}^{+}\right]$. The plot of $\log \mathrm{k}_{1}$ versus $\log \left[\mathrm{IO}_{4}\right]$ (Figure 1) gave a slope of 1.00 with respect to $\left[\mathrm{H}^{+}\right]$. Similar result has been reported on redox reaction of orange II with chlorate ion (Myek et al., 2020). The Plot of $\mathrm{k}_{2}$ versus $\left[\mathrm{H}^{+}\right]$was linear with a positive intercept $\left(\mathrm{R}^{2}=0.89\right)$. The acid dependence of this nature shows that there is a rapid pre-equilibrium between the protonated and non-protonated forms in which both the protonated and unprotonated forms are reactive (Onu et al., 2019).

The result obtained for the effect of changes in ionic strength (Table 1) showed that the rate of reaction increases with increase in ionic strength of the reaction medium. This obeys a positive BrØnsted - Debye salt effect, implying that the rate determining step is composed of reactants of like charges (Ayodele et al., 2004; Myek et al., 2018). Slope of 0.39 was obtained from the plot of $l o g k_{2}$ against $\mathrm{I}^{1 / 2}\left(\mathrm{R}^{2}=0.92\right)$ (Figure 2$)$. This signified that the product of their charges was 0.39 which is an indication that some other interactions might have taken place to account for the non-integral value for the products of the species at the transition state (Idris, 2005). The effect of added cations (Table 3) inhibited the rate of the reaction. This was unexpected as the cations were expected to increase the rate of the reaction due to the fact that anions are participating in the rate determining step. Addition of $\mathrm{CH}_{3} \mathrm{COO}^{-}$and $\mathrm{SO}_{4}^{2-}$ to the reaction accelerated the rate of the reaction thereby supported an outer sphere mechanism. Plot of $1 / \mathrm{k}_{1}$ versus $1 /\left[\mathrm{IO}_{4}\right]$ (Figure 3) gave no intercept suggesting absence of intermediate complex formation.

Addition of acrylonitrile to a partially reacted mixture in the presence of excess methanol did not lead to gel formation. This shows that the participation of free radicals in this reaction is unlikely. Similar result has been reported for $\mathrm{Mn}(\mathrm{II})$ catalyzed periodate oxidation of $\mathrm{p}$ anisidine (Kaushik et al., 2014). The UV-vis spectrum of the reaction mixture when compared to that of dye (OR) alone showed no shift in $\lambda_{\max }$ suggesting absence of an intermediate complex during the reaction.

Based on the results obtained, the evidence suggests that this reaction is probably operating by the outer sphere mechanism. From the results, the plausible mechanism is given in equations $4-8$.

Table 1: Pseudo - first order and second order rate constants for the OR and $\mathrm{IO}_{4}^{-}$at $[\mathrm{OR}]=5.0 \times 10^{-5} \mathrm{~mol} \mathrm{dm}{ }^{-3}, \lambda=480 \mathrm{~nm}$ and $\mathrm{T}=23 \pm 1^{\circ} \mathrm{C}$

\begin{tabular}{|c|c|c|c|c|}
\hline $\begin{array}{l}10^{3}\left[\mathrm{IO}_{4}^{-}\right], \\
\mathrm{mol} \mathrm{dm}^{-3}\end{array}$ & $\begin{array}{l}10^{2}\left[\mathrm{H}^{+}\right] \\
\mathrm{mol} \mathrm{dm}\end{array}$ & $\begin{array}{l}\mathrm{I}, \\
\mathrm{C}^{2} \mathrm{~mol} \mathrm{dm}\end{array}$ & $\begin{array}{l}10^{3} \mathrm{k}_{1} \\
\mathrm{~s}^{-1}\end{array}$ & $\begin{array}{l}\mathrm{k}_{2,} \\
\mathrm{dm}^{3} \mathrm{~mol}^{-1} \mathrm{~s}^{-1}\end{array}$ \\
\hline 4.8 & 5.0 & 0.5 & 2.30 & 0.479 \\
\hline 5.6 & 5.0 & 0.5 & 2.70 & 0.482 \\
\hline 6.4 & 5.0 & 0.5 & 3.07 & 0.480 \\
\hline 7.2 & 5.0 & 0.5 & 3.48 & 0.483 \\
\hline 8.0 & 5.0 & 0.5 & 3.84 & 0.480 \\
\hline 8.8 & 5.0 & 0.5 & 4.23 & 0.480 \\
\hline 6.4 & 2.0 & 0.5 & 1.27 & 0.198 \\
\hline 6.4 & 3.0 & 0.5 & 1.36 & 0.213 \\
\hline 6.4 & 4.0 & 0.5 & 2.25 & 0.351 \\
\hline 6.4 & 5.0 & 0.5 & 3.07 & 0.480 \\
\hline 6.4 & 8.0 & 0.5 & 3.34 & 0.522 \\
\hline 6.4 & 10.0 & 0.5 & 3.58 & 0.560 \\
\hline 6.4 & 5.0 & 0.2 & 1.06 & 0.166 \\
\hline 6.4 & 5.0 & 0.3 & 1.60 & 0.250 \\
\hline 6.4 & 5.0 & 0.4 & 2.44 & 0.382 \\
\hline 6.4 & 5.0 & 0.5 & 3.08 & 0.481 \\
\hline 6.4 & 5.0 & 0.7 & 3.41 & 0.533 \\
\hline 6.4 & 5.0 & 0.8 & 3.96 & 0.618 \\
\hline
\end{tabular}


026 Myek et al.: Kinetics and Mechanism of the Oxidation of Orange II By Periodate Ion in Aqueous Acid

Table 2: Rate data for the effect of added anions $\left(\mathrm{CH}_{3} \mathrm{COO}^{-}\right.$and $\left.\mathrm{SO}_{4}{ }^{2}\right)$ on the rate of reaction of $\mathrm{OR}^{-}$ and $\mathrm{IO}_{4}^{-}$at $[\mathrm{OR}]=5.0 \times 10^{-5} \mathrm{moldm}^{-3},\left[\mathrm{IO}_{4}\right]=6.4 \times 10^{-3} \mathrm{moldm}^{-3},\left[\mathrm{H}^{+}\right]=5.0 \times 10^{-2} \mathrm{moldm}^{-3}, \mathrm{I}=$ $0.50 \mathrm{C}^{2}$ moldm ${ }^{-3}, \lambda=484 \mathrm{~nm}$ and $\mathrm{T}=23 \pm 1{ }^{\circ} \mathrm{C} \mathrm{moldm}^{-3}$

\begin{tabular}{llll}
\hline Ion & $\begin{array}{c}10^{3}[\text { ion }], \\
\mathrm{mol} \mathrm{dm}\end{array}$ & $\begin{array}{c}10^{3} \mathrm{k}_{1}, \\
\mathrm{~s}^{-1}\end{array}$ & $\begin{array}{c}\mathrm{k}_{2}, \\
\mathrm{dm}^{3} \mathrm{~mol}^{-1} \mathrm{~s}^{-1}\end{array}$ \\
\hline $\mathrm{CH}_{3} \mathrm{COO}^{-}$ & 0.0 & 2.69 & 0.480 \\
& 10.0 & 2.96 & 0.529 \\
20.0 & 3.38 & 0.604 \\
& 40.0 & 3.85 & 0.688 \\
& 60.0 & 4.22 & 0.754 \\
& 80.0 & 4.67 & 0.834 \\
& 100.0 & 5.19 & 0.927 \\
$\mathrm{SO}_{4}{ }^{2-}$ & & 2.69 & 0.481 \\
& 0.0 & 2.83 & 0.506 \\
& 10.0 & 3.04 & 0.543 \\
& 20.0 & 3.65 & 0.651 \\
& 40.0 & 4.12 & 0.736 \\
& 60.0 & 4.45 & 0.794 \\
& 100.0 & 4.63 & 0.827 \\
\hline
\end{tabular}

Table 3: Rate data for the effect of added cations $\left(\mathrm{Ca}^{2+}\right.$ and $\left.\mathrm{Mg}^{2+}\right)$ on the rate of reaction of OR and $\mathrm{IO}_{4}^{-}$at $[\mathrm{OR}]=5.0 \times 10^{-5} \mathrm{moldm}^{-3},\left[\mathrm{IO}_{4}\right]=6.4 \times 10^{-3} \mathrm{moldm}^{-3},\left[\mathrm{H}^{+}\right]=5.0 \times 10^{-2} \mathrm{moldm}^{-3}, \mathrm{I}=0.50$ $\mathrm{C}^{2} \mathrm{~mol} \mathrm{dm}{ }^{-3}, \lambda=484 \mathrm{~nm}$ and $\mathrm{T}=23 \pm 1{ }^{\circ} \mathrm{C}$

\begin{tabular}{cccc}
\hline Ion & $\begin{array}{c}10^{3}[\mathrm{ion}], \\
\mathrm{mol} \mathrm{dm}\end{array}$ & $\begin{array}{l}10^{3} \mathrm{k}_{1}, \\
\mathrm{~s}^{-3}\end{array}$ & $\begin{array}{l}\mathrm{k}_{2}, \\
\mathrm{dm}^{3} \mathrm{~mol}^{-1} \mathrm{~s}^{-1}\end{array}$ \\
\hline $\mathrm{Ca}^{2+}$ & & & \\
& 0.0 & 3.08 & 0.482 \\
& 2.0 & 2.24 & 0.350 \\
& 40.0 & 1.82 & 0.316 \\
& 60.0 & 1.54 & 0.284 \\
& 80.0 & 1.20 & 0.240 \\
& 100.0 & 0.934 & 0.187 \\
$\mathrm{Mg}^{2+}$ & 0.80 & 0.146 \\
& 150.0 & 3.07 & 0.125 \\
& 0.0 & 2.82 & 0.480 \\
& 10.0 & 2.52 & 0.440 \\
& 20.0 & 2.25 & 0.393 \\
& 60.0 & 1.69 & 0.352 \\
& 80.0 & 1.41 & 0.264 \\
& 100.0 & 1.08 & 0.221 \\
& 150.0 & 0.742 & 0.168 \\
& & & 0.116 \\
\hline
\end{tabular}




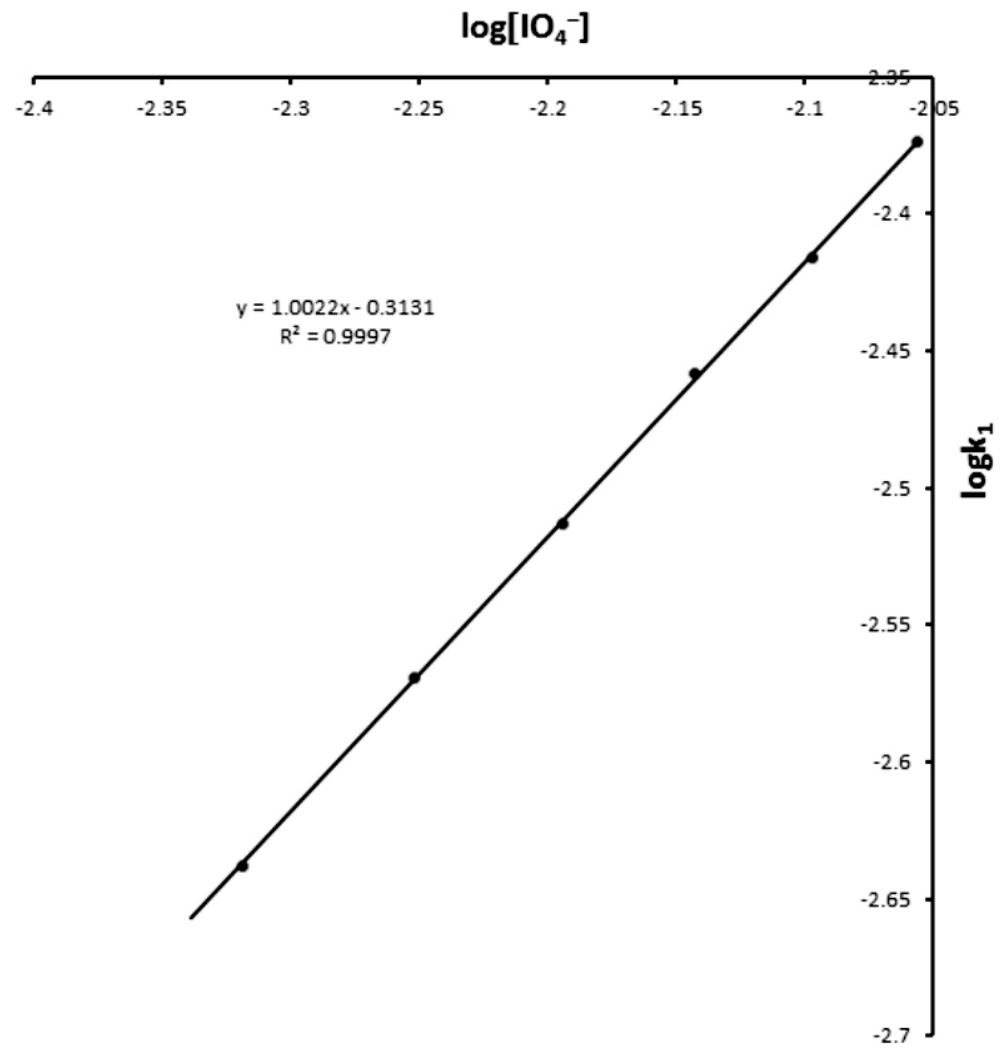

Figure 1: Plot of $\log \mathrm{k}_{1}$ versus $\log \left[\mathrm{IO}_{4}\right]$ for the redox reaction of $\mathrm{OR}^{-}$with $\mathrm{IO}_{4}^{-}$at $[\mathrm{OR}]=$ $5.0 \times 10^{-5} \mathrm{moldm}^{-3},\left[\mathrm{IO}_{4}\right]=(4.8-8.8) \times 10^{-3} \mathrm{moldm}^{-3},\left[\mathrm{H}^{+}\right]=5.0 \times 10^{-2} \mathrm{moldm}^{-3}, \mathrm{I}=0.50 \mathrm{C}^{2} \mathrm{~mol}$ $\mathrm{dm}^{-3}, \lambda=484 \mathrm{~nm}$ and $\mathrm{T}=23 \pm 1^{\circ} \mathrm{C}$

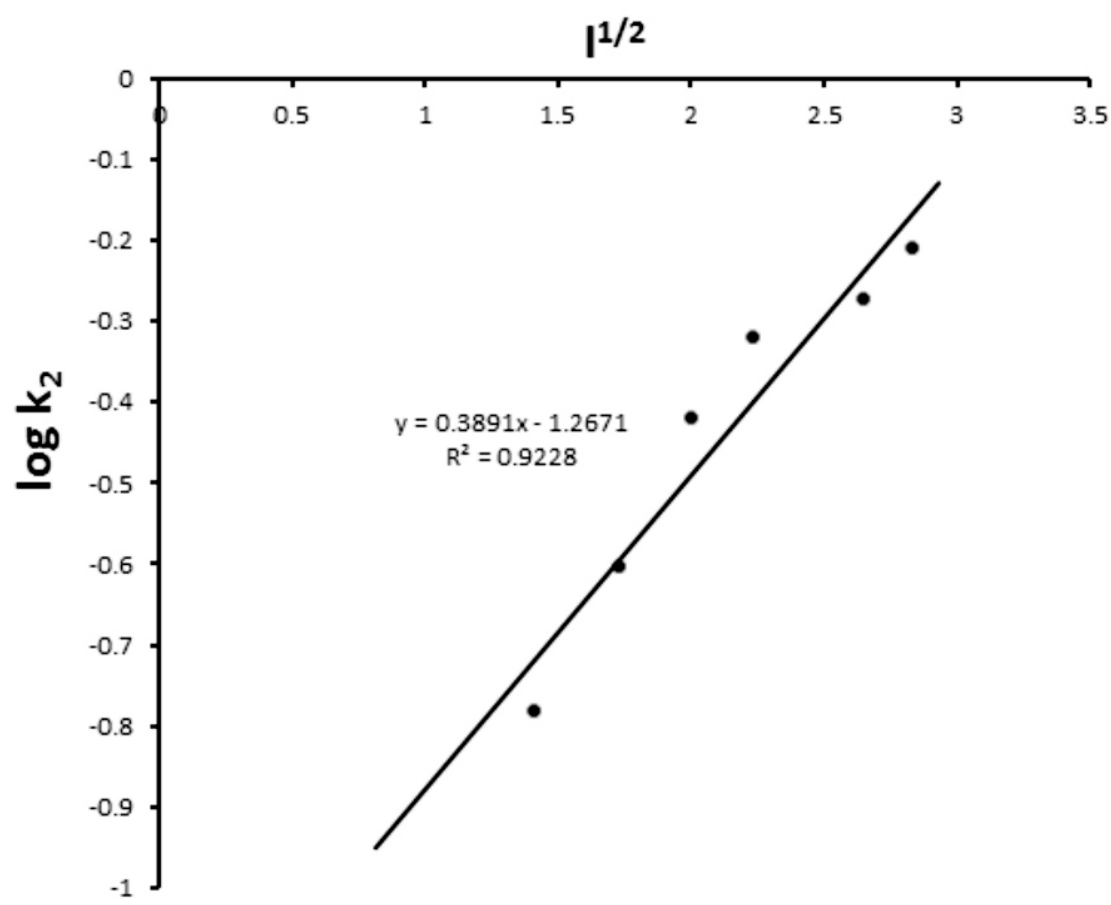

Figure 2: Plot of $\log \mathrm{k}_{2}$ versus $\mathrm{I}^{1 / 2}$ for the redox reaction between $\mathrm{OR}^{-}$and $\mathrm{IO}_{4}^{-}$at $[\mathrm{OR}]=5.0 \times$ $10^{-5} \mathrm{moldm}^{-3},\left[\mathrm{IO}_{4}\right]=6.4 \times 10^{-3} \mathrm{moldm}^{-3},\left[\mathrm{H}^{+}\right]=5.0 \times 10^{-2} \mathrm{moldm}^{-3}, \mathrm{I}=0.50 \mathrm{C}^{2} \mathrm{~mol} \mathrm{dm}^{-3}, \lambda=$ $484 \mathrm{~nm}$ and $\mathrm{T}=23 \pm 1^{\circ} \mathrm{C}$ 


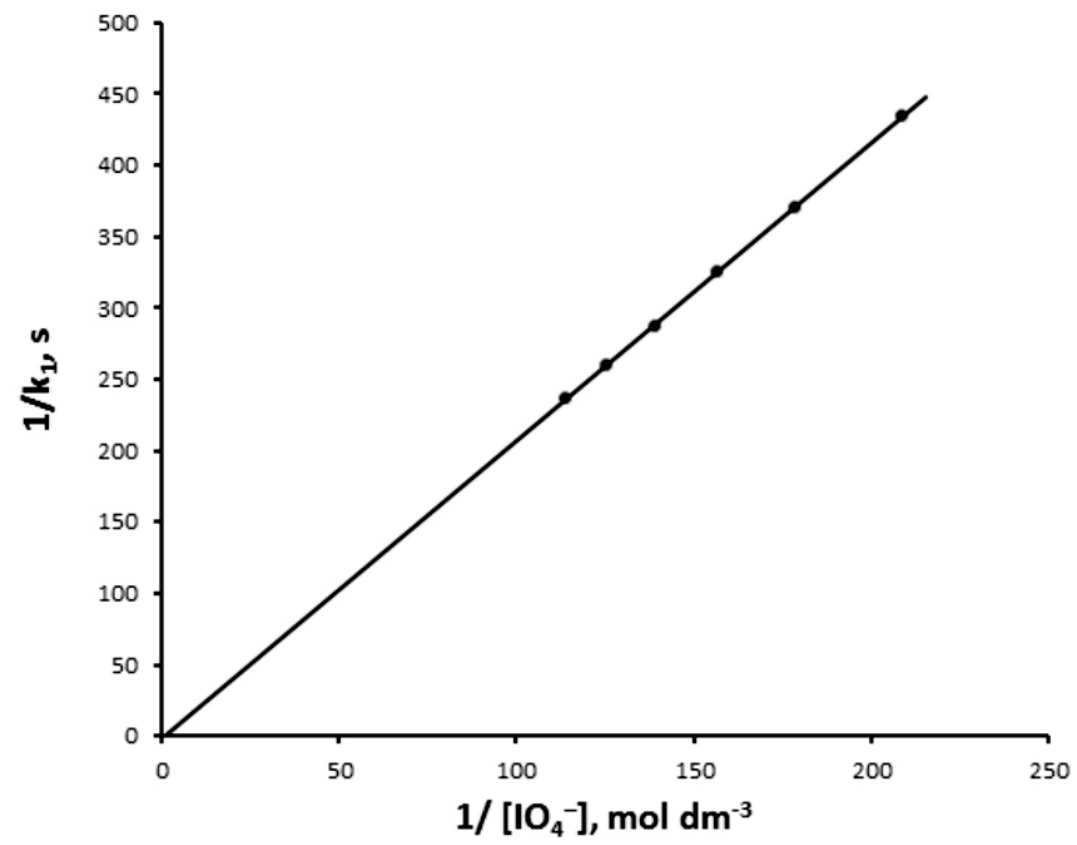

Figure 3: Michaelis - Menten plot for the redox reaction between $\mathrm{OR}^{-}$and $\mathrm{IO}_{4}$ at $[\mathrm{OR}]=5.0 \times$ $10^{-5} \mathrm{moldm}^{-3},\left[\mathrm{IO}_{4}\right]=(4.8-8.8) \times 10^{-3} \mathrm{moldm}^{-3},\left[\mathrm{H}^{+}\right]=5.0 \times 10^{-2} \mathrm{moldm}^{-3}, \mathrm{I}=0.50 \mathrm{C}^{2} \mathrm{~mol}$ $\mathrm{dm}^{-3}, \lambda=484 \mathrm{~nm}$ and $\mathrm{T}=23 \pm 1^{\circ} \mathrm{C}$

Reaction Mechanism

$$
\mathrm{OO}_{4}^{-}+\mathrm{H}^{+} \stackrel{\mathrm{K}_{1}}{\rightleftarrows} \mathrm{HIO}_{4}
$$

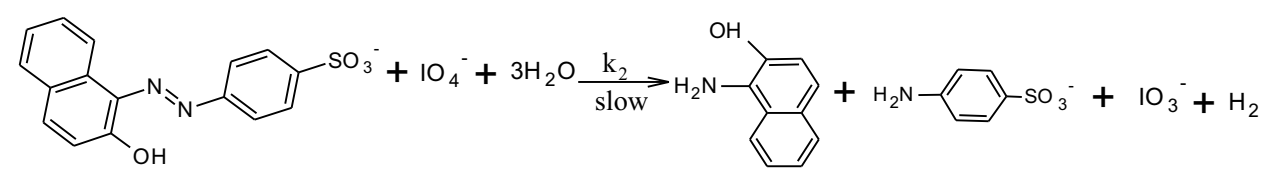

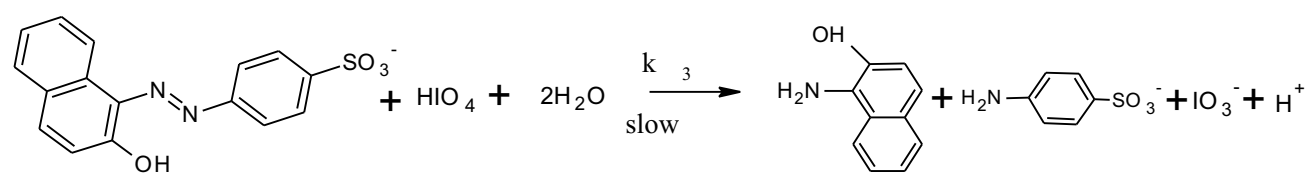

$$
\begin{aligned}
& \text { Rate }=\mathrm{k}_{2}\left[\mathrm{OR}^{-}\right]\left[1 \mathrm{OO}_{4}^{-}\right]+\mathrm{k}_{3} \mathrm{~K}_{1}\left[\mathrm{OR}^{-}\right]\left[\mathrm{IO}_{4}^{-}\right]\left[\mathrm{H}^{+}\right] \\
& =\left(\mathrm{k}_{2}+\mathrm{k}_{3} \mathrm{~K}_{1}\left[\mathrm{H}^{+}\right]\right)\left[\mathrm{OR}^{-}\right]\left[1 \mathrm{O}_{4}^{-}\right]
\end{aligned}
$$

Equation 8 is analogous to equation 3 where $a=k_{2}$ and $b=k_{3} K_{1}$

\section{CONCLUSION}

The redox reaction of $\mathrm{OR}^{-}$and periodate ion in acidic medium has been carried out in this study. The results showed a stoichiometry of $1: 1$, and a first order reaction was observed for $\mathrm{OR}^{-}$and $\mathrm{IO}_{4}^{-}$ ions. The rate constant increases with increase in acid concentration. Added cations inhibited the rate of the reaction. Michaelis-Mentein's plot of $1 / k_{1}$ versus $1 /\left[\mathrm{IO}_{4}\right]$ had no intercept. Based on the above results, it is proposed that the reaction operates probably through the outersphere mechanism.

\section{REFERENCES}

Ayodele, E.T., Olajire, A.A., and Oladoye, S.O. (2000). Kinetics of periodate oxidation of tris-(4,4'-dimethyl-2,2'-bypyridine) iron(II) in acid medium. Bulletin of the 
Myek et al.: Kinetics and Mechanism of the Oxidation of Orange II By Periodate Ion in Aqueous Acid

chemical society of Ethiopian, 14(2): 175-184

Babatunde, O.A., and Nwakama O.N. (2013).Kinetic approach to the mechanism of oxidation of L-Ascorbic acid by periodate ion in acidic medium. Journal of biology and life science, $4(2): 32-42$

David, C. (2008). Synthesis and use of fabric dyes. Chemical, environmental and biotechnology department, college of applied arts and technology, Mohawk, Canada. Pp 1-20.

Edokpayi, J, N. (2011). Kinetics and mechanism of redox reaction of disodium 3,3'dioxobi-indoline-2, 2'-ylidene-5, 5' disulphonate with some oxy-anions in aqueous acidic solution, unpublished M.Sc thesis, Ahmadu Bello University, Zaria.

Gapala, K.S., Nevaditha, N. T., and Myhili C.V. (2011). Antibacterial activity of azo compounds synthesized from the natural renewable source, Cardanol journal of chemical and pharmaceutical research., 3(4): 490 $-497$.

Idris, S.O., Hassan, H., Iyun, J.F., and Mohammed, Y. (2015).Kinetic and mechanism of the periodate oxidation of malachite green in acidic medium. Journal of scientific research \& reports 4(6):551-560.

Idris, S.O. (2005). Some electron transfer reactions of $\mathrm{Cr}(\mathrm{VI})$ and of tetrakis $(2,2$-bipyridine $)-\mu$-oxodiiron(III) complex, published Ph.D thesis, Ahmadu Bello University, Zaria.

Ismail, I. M., Ewais, H. A., and Elroby, Sh.A.K. (2014) Kinetics and mechanism of periodate oxidation of ternary orotatochromium(III) complexes bearing oxalate or malonate co-igands, Rusians chemical bulletin, 63: 591-598.

Kaushik, R. D., Yadav, R., Manila, M. K., and Singh, J. (2014). Kinetics of oxidation of methyldopa by periodate ion in aqueous medium. International journal of pharmaceutical research, 6(5): 1509-1517.

Kaushik, R. D., Singh, J., Manila, M., Kaur, M., and Singh, P. (2014). Kinetics and Mechanism of $\mathrm{Mn}(\mathrm{II})$ catalyzed periodate oxidation of $\mathrm{p}$-anisidine:Effect of $\mathrm{pH}$. Bulletin of chemical engineering \& catalysis, 9 (3): 182-191

Mohammed, Y. (2005). Kinetics and mechanisms of the electrontransfer reactions of diaquotetrakis (2, 2'-bipyridine)- $\mu$ oxodiruthenium(III) ions andsome reductants in aqueous medium. Published Ph.D thesis, Ahmadu Bello University, Zaria.

Myek, B., Idris, S.O., Onu, A.D., and Yakubu, M. K. (2000). Kinetics of the oxidation of orange II by chlorate ion in Aqueous Hydrochloric Acid. Communication in physical chemistry, 5(2): 165-170.

Myek, B., Idris, S.O., Onu, A.D., and Yakubu, M. K. (2018). Kinetics and mechanism of the oxidation of orange II by permanganate ion in Aqueous acidic medium. Nigerian research journal of chemical sciences, 5: 98-107.

Myek, B., Idris, S.O., and Iyun, J.F. (2013). Kinetics of the oxidation of naphthol green B by periodate ion in aqueous hydrochloric acid medium. International Journal of modern chemistry., 5(2): $127-135$.

Naik, R.M., Srivastava, A., and Asthana, A. (2008). The kinetics and mechanism of oxidation of hexacyanoferrate(II) by periodate ion in highly alkaline aqueous medium. Journal of the Iranian chemical society, 5:29-36.

Olayinka, O.A., Oluwabunmi E.A., Alice O.A., Abiola E., and Winifred, U.A. (2013). Synthesis and spectroscopic study of naphtholic and phenolic azo dyes. Physical review research international, $3(1): 28-41$

Onu, A.D., Iyun, J. F., and Idris, S.O. (2019). Kinetics of the oxidation of orange II by nitrite ion in aqueous acidic medium, FULafia journal of science \& technology, 5(1): 36-40

Onu, A.D., Iyun, J. F., and Idris, S.O. (2019). The kinetics of the oxidation of thiosulphates ions by copper ions in aqueous ammonia solution. Journal of chemical society, dalton transactions. 8: 889-893.

Shizuo N., and Makoto S. (2012). Comparative study on the decolorization of orange II by zero-valence tin in citric and hydrochloric acids. Energy and environment research; 2(1): 1-12.

Svehla, G., and Sivasankar's, B. (2012). Vogel's qualitative inorganic analysis. Pearson, London, 254: 341-342.

Zainab, A.A., Balgis, W.K., and Amer J.J. (2013). Synthesis, characterization of new azo 
030 Myek et al.: Kinetics and Mechanism of the Oxidation of Orange II By Periodate Ion in Aqueous Acid compounds and studies effect on the ach enzyme (In vitro). Internatonal Journal of engineering science and technology., 2(2): 326 334. 